\title{
Familial association of pancreatic cancer with other malignancies in Swedish families
}

\author{
E Hiripi*,', J Lorenzo Bermejo', X Li², J Sundquist ${ }^{3,4}$ and K Hemminki ${ }^{1,2,3}$ \\ 'Division of Molecular Genetic Epidemiology, German Cancer Research Center (DKFZ) Im Neuenheimer Feld 580, 69I 20, Germany; ${ }^{2}$ Karolinska \\ Institute, Center for Family and Community Medicine, 14183 Huddinge, Sweden; ${ }^{3}$ Center for Primary Health Care Research, Lund University, Malmö, \\ Sweden; ${ }^{4}$ Stanford Prevention Research Center, Stanford University School of Medicine, California, USA
}

BACKGROUND:The aim of this study was to characterise the familial association of pancreatic cancer with other malignancies. METHODS: Relative risks (RRs) of pancreatic cancer according to family history of cancer were calculated using the updated Swedish Family-Cancer Database, which includes over I I.5 million individuals. Estimates were based on Poisson regression. RRs of tumours for individuals with a parental history of pancreatic cancer were also estimated.

RESULTS: The risk of pancreatic cancer was elevated in individuals with a parental history of cancers of the liver (RR I.4I; 95\%

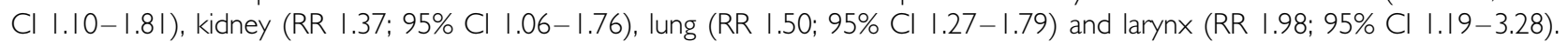
Associations were also found between parental history of pancreatic cancer and cancers of the small intestine, colon, breast, lung, testis and cervix in offspring. There was an increased risk of pancreatic cancer associated with early-onset breast cancer in siblings. CONCLUSION: Pancreatic cancer aggregates in families with several types of cancer. Smoking may contribute to the familial aggregation of pancreatic and lung tumours, and the familial clustering of pancreatic and breast cancer could be partially explained by inherited mutations in the BRCA2 gene.

British Journal of Cancer (2009) I 0 I, 1792- 1797. doi:I0.1038/sj.bjc.6605363 www.bjcancer.com

Published online 13 October 2009

(C) 2009 Cancer Research UK

Keywords: familial risk; pancreatic cancer; family history

Pancreatic cancer is the fourth most common cause of death from cancer in Sweden (Hemminki and Li, 2003a; Linder et al, 2007). Prognosis for patients with this disease is very poor: the median survival time is 6 months and the 5-year survival rate is below $10 \%$ (Rulyak and Brentnall, 2004; Ghaneh et al, 2007; Linder et al, 2007). Early treatment of pancreatic cancer increases the likelihood of survival (Greenhalf and Neoptolemos, 2006). However, most patients are diagnosed at an advanced stage (Klein et al, 2002; Greer et al, 2007). Studying the familial clustering of pancreatic cancer with non-pancreatic malignancies meets two objectives: it provides information for cancer risk assessment in genetic counselling and provides clues with regard to the aetiology of the disease.

Around $4 \%$ of patients diagnosed with pancreatic cancer have parents or siblings who are also affected by pancreatic cancer (Hemminki et al, 2008). It has been estimated that up to $20 \%$ of the familial clustering of pancreatic cancer can be attributed to syndromes such as hereditary non-polyposis colon cancer (HNPCC), familial adenomatous polyposis and familial atypical multiple mole melanoma syndrome (Klein et al, 2001; Jaffee et al, 2002). The corresponding genes associated with these disorders are mismatch repair genes, $A P C$ and CDKN2A (Klein et al, 2001; Lynch and de la Chapelle, 2003). Other reported risk factors for the disease are tobacco smoking, obesity and diet rich in calories and

*Correspondence: Dr E Hiripi; E-mail: e.hiripi@dkfz-heidelberg.de Received 29 January 2009; revised II September 2009; accepted 14 September 2009; published online 13 October 2009 meat (Coughlin et al, 2000; Chiu et al, 2001; Michaud et al, 2001; MacLeod and Chowdhury, 2006; Ghaneh et al, 2007).

The present population-based study used the Swedish FamilyCancer Database. An important advantage of the database is that information on familial relationships and cancers comes from registered sources of practically complete coverage, thus offering unique possibilities for precise and unbiased assessment. The risks of pancreatic cancer were estimated according to family history of the most prevalent types of cancer. Risks of non-pancreatic malignancies for individuals with a family history of pancreatic cancer were also calculated. The database has been used previously to assess the association of pancreatic cancer with parental history of cancers from 1961 to 1998 (Hemminki and Li, 2003a). The database was updated in 2006 and now includes over 1.2 million tumours diagnosed between 1958 and 2004. Compared with the previous version, the number of pancreatic cancer patients with a parental history of the disease increased from 34 to 84 patients. Using the updated database, we explored the risk of pancreatic cancer according to sibling history of cancer as well. As early age of onset has been a reported characteristic of hereditary cancer, we additionally calculated the relative risks of pancreatic cancer according to the parental/sibling age of diagnosis of cancer (Krainer et al, 1997; Raimondi et al, 2007).

\section{PATIENTS AND METHODS}

Data on the incidence of pancreatic cancer between 1961 and 2004 in Sweden were derived from the Nordcan Database (Engholm 
et al, 2008). Relative risks of pancreatic and other cancers were calculated using the updated Swedish Family-Cancer Database. The population-based Swedish Family-Cancer Database was created by linking the Multigeneration Register at Statistics Sweden to the Swedish Cancer Registry (Hemminki et al, 2001). The Multigeneration Register includes individuals born in Sweden after 1931 and their biological parents. The Swedish Cancer Registry is based on compulsory reports about patients provided by pathologists and cytologists, who report every cancer diagnosis on surgically removed tissues, biopsies, cytological specimens, bone marrow aspirates and autopsies (Center for Epidemiology, 2004). The latest update of the database comprises more than 11.5 million individuals. Data on patients with cancer were retrieved from the Swedish Cancer Registry from 1961 to 2004. The coverage of the database is practically complete; however, some familial links are missing from offspring who were born before 1941 and who died between 1960 and 1997. The effect of the missing data is a reduced number of mortal cancers among offspring. This is unlikely to cause bias to familial studies because familial and sporadic cases would be reduced proportionately (Hemminki et al, 1998; Hemminki and Vaittinen, 1999). This study relies on individuals who had information available about both parents. Family history was restricted to first-degree relatives, that is, to parents and siblings.

Follow-up started from the date of birth, immigration or from 1 January 1961, whichever occurred last. Follow-up ended on the date of diagnosis of first cancer, on death, emigration or on the closing date of the study (31 December 2004), whichever came first. Cases of cancer and person-years were classified according to gender, family history of cancer, calendar year, age, socioeconomic status and geographical region. The distribution of the number of cases in each group was modelled by Poisson regression. We controlled for family history of cancer, gender, calendar year, age, socioeconomic status and geographical region in all models. In addition, dichotomous variables were created according to parental/sibling age of diagnosis with cancer $(0-55 ; 56-71 ; 72$ or older $)$.

The Genmod procedure of SAS software was used for the analysis (SAS Version 9.1; SAS Institute, Cary, NC, USA). Standard Poisson regression assumes independent observations. To account for the possible overdispersion because of a clustered family structure, s.e. can be adjusted using Pearson's $\chi^{2}$-test, divided by degrees of freedom. The adjustment results in slightly wider confidence intervals. For example, the relative risk (RR) of pancreatic cancer for individuals with a family history of pancreatic cancer was 2.11 $(95 \% \mathrm{CI}=1.67-2.66)$ after adjustment and $2.11(95 \%=\mathrm{CI} 1.73-$ 2.57) without adjustment. However, this procedure may be particularly sensitive to outlying observations that are expected in our large data set. Therefore, we show in this article unadjusted CIs and point to the possibility of conservative limits due to familial dependence. The tables in this study show only cancer sites with significant results or with at least 30 affected parent-offspring pairs.

Risk of pancreatic cancer in hereditary pancreatitis was analysed by identifying hospitalised cases of chronic pancreatitis through the Swedish Hospital Discharge Register, containing all hospitalisations in Sweden between 1964 and 2007, but with a nationwide coverage only since 1987 (for description, see (Hemminki et al, 2009)). Familial pancreatitis was defined when at least two family members were hospitalised with this disease. Pancreatic cancers in any family members were scored through the Cancer Registry. Similarly, patients hospitalised for cystic fibrosis were identified and their subsequent pancreatic cancers were retrieved from the Cancer Registry.

\section{RESULTS}

Age-standardised incidence of pancreatic cancer in Sweden in the period 1961-2004 is shown in Figure 1. The incidence of pancreatic cancer in this period is stable, except from a spike in

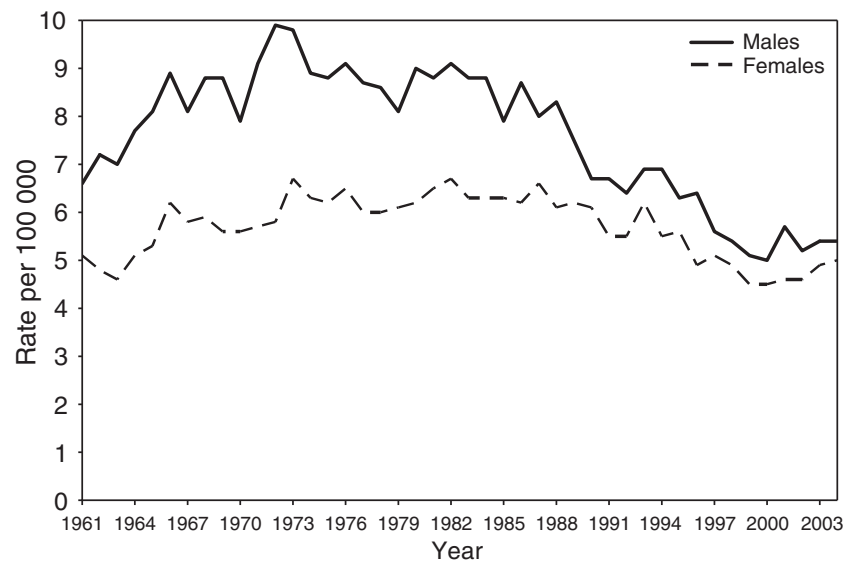

Figure I Age-standardised incidence of pancreatic cancer/100000 individuals in Sweden in |96|-2004 (adjusted to world standard population)

Table I Relative risk of pancreatic cancer according to sex, age and family history of pancreatic cancer

\begin{tabular}{|c|c|c|c|}
\hline Covariate & Level & $\mathbf{N}$ & $\operatorname{RR}(95 \% \mathrm{Cl})$ \\
\hline Gender & $\begin{array}{l}\text { Females } \\
\text { Males }\end{array}$ & $\begin{array}{l}1314 \\
1502\end{array}$ & $\begin{array}{l}\mathbf{0 . 8 6} \text { (0.75-0.97) } \\
1.00 \text { (ref.) }\end{array}$ \\
\hline Age of diagnosis (years) & $\begin{array}{l}\text { Before } 50 \\
50-54 \\
55-59 \\
60 \text { and above }\end{array}$ & $\begin{array}{r}507 \\
502 \\
751 \\
1056\end{array}$ & $\begin{array}{l}\mathbf{0 . 0 3}(0.03-0.04) \\
\mathbf{0 . 3 2}(0.28-0.35) \\
\mathbf{0 . 6 0}(0.55-0.66) \\
1.00(\text { ref })\end{array}$ \\
\hline $\begin{array}{l}\text { Family history } \\
\text { of pancreatic cancer }\end{array}$ & $\begin{array}{l}\text { Yes } \\
\text { No }\end{array}$ & $\begin{array}{r}103 \\
2713\end{array}$ & $\begin{array}{l}2.11 \text { ( } 1.73-2.57) \\
1.00 \text { (ref.) }\end{array}$ \\
\hline
\end{tabular}

Bold signifies $P<0.05$

the early 1970 s among men. The proportion of pancreatic cancer patients with a parent or sibling affected by the disease was $3.66 \%$ $(N=103)$.

Table 1 provides the results of a multivariate Poisson regression that included a dichotomous variable for family history of pancreatic cancer diagnosed at any age, in addition to gender, calendar year, age, socioeconomic status and geographical region: women were at a slightly lower risk of pancreatic cancer compared with men (RR 0.86; 95\% CI 0.75-0.97). As expected, age was found to be associated with the risk of developing pancreatic cancer. The risk of pancreatic cancer was increased among individuals with a family history of the malignancy (RR 2.11 ; 95\% CI 1.73-2.57). Individuals with a parent diagnosed with pancreatic cancer are at an increased risk of developing pancreatic cancer (RR 1.93; 95\% CI 1.55-2.40) (Table 2). There was an increased risk of pancreatic cancer among the offspring of patients with cancers of the liver (RR 1.41; 95\% CI 1.10-1.81), larynx (RR 1.98; 95\% CI 1.19-3.28), lungs (RR 1.50; 95\% CI 1.27-1.79) and kidneys (RR 1.37; 95\% CI $1.06-1.76)$.

In contrast, we also examined the risk of tumours in the offspring of pancreatic cancer patients (Table 3). There was an increased risk of cancer of the small intestine (RR 1.62; 95\% CI $1.02-2.55$ ) and colon (RR 1.28; 95\% CI 1.10-1.48) among those with a parental history of pancreatic cancer. Parental pancreatic cancer was associated with an increased risk of melanoma in the offspring (RR 1.25; 95\% CI 1.10-1.42). The offspring of patients with pancreatic cancer were at a higher risk of cancers of the liver (RR 1.52; 95\% CI 1.17-1.98), lung (RR 1.18; 95\% CI 1.02-1.36) and the breast (RR $1.21 ; 95 \%$ CI $1.13-1.31)$. Women with a parental history of pancreatic cancer had an increased risk of developing cervical cancer (RR 1.44; 95\% CI 1.18-1.76). Sons of 
Table 2 Relative risks of pancreatic cancer (RR) for the offspring of individuals affected by cancer

\begin{tabular}{|c|c|c|c|c|c|c|c|c|}
\hline \multirow[b]{3}{*}{ Parental cancer site } & \multicolumn{8}{|c|}{ Parental age of diagnosis with cancer } \\
\hline & \multicolumn{2}{|r|}{ Any age } & \multicolumn{2}{|r|}{$0-55$} & \multicolumn{2}{|r|}{$56-71$} & \multicolumn{2}{|r|}{$72+$} \\
\hline & $\mathbf{N}$ & RR (95\% CI) & $\mathbf{N}$ & $\mathbf{R R}(95 \% \mathbf{C I})$ & $\mathbf{N}$ & $\mathbf{R R}(95 \% \mathrm{Cl})$ & $\mathbf{N}$ & $\mathbf{R R}(95 \% \mathrm{CI})$ \\
\hline Upper aerodigestive tract & 25 & $1.06(0.7|-| .56)$ & 5 & $1.79(0.75-4.31)$ & 13 & $1.15(0.67-1.99)$ & 7 & $0.74(0.35-1.55)$ \\
\hline Oesophagus & || & $0.98(0.54-1.77)$ & & & 5 & $0.98(0.4 I-2.35)$ & 5 & $0.93(0.39-2.24)$ \\
\hline Stomach & 82 & $1.09(0.87-1.36)$ & 8 & $1.25(0.63-2.51)$ & 36 & $1.09(0.78-1.51)$ & 38 & $1.08(0.78-1.48)$ \\
\hline Small intestine & 3 & $0.53(0.17-1.64)$ & & & & & & \\
\hline Colon & 109 & $1.03(0.85-1.25)$ & 13 & $1.62(0.94-2.80)$ & 42 & $1.02(0.75-1.39)$ & 54 & $0.97(0.74-1.27)$ \\
\hline Rectum & 73 & $1.23(0.97-1.55)$ & 6 & $1.20(0.54-2.67)$ & 28 & $1.13(0.78-1.65)$ & 39 & $1.33(0.97-1.82)$ \\
\hline Liver & 63 & $1.41(1.10-1.81)$ & 4 & $1.67(0.63-4.45)$ & 13 & $0.72(0.42-1.24)$ & 46 & $\mathbf{I . 9 0}(1.42-2.55)$ \\
\hline Pancreas & 84 & $\mathbf{I . 9 3}(1.55-2.40)$ & 10 & $3.32(1.78-6.18)$ & 41 & $2.19(1.61-2.98)$ & 33 & $\mathbf{I . 5 4}(1.09-2.17)$ \\
\hline Larynx & 15 & $1.98(1.19-3.28)$ & & & 8 & $1.96(0.98-3.92)$ & 6 & $2.41(1.08-5.37)$ \\
\hline Lung & 136 & $\mathbf{I . 5 0}(1.27-1.79)$ & 20 & $2.52(1.62-3.92)$ & 56 & $1.26(0.96-1.64)$ & 60 & $\mathbf{I . 5 8}(1.22-2.04)$ \\
\hline Breast & 156 & $1.12(0.95-1.32)$ & 27 & $1.02(0.70-1.49)$ & 76 & $1.25(1.00-1.58)$ & 53 & $1.05(0.80-1.37)$ \\
\hline Cervix uteri & 18 & $0.68(0.43-1.08)$ & 9 & $0.71(0.37-1.37)$ & 8 & $0.81(0.41-1.63)$ & & \\
\hline Endometrium & 41 & $1.19(0.87-1.62)$ & 10 & $1.61(0.86-2.99)$ & 21 & $1.27(0.82-1.95)$ & 10 & $0.88(0.47-1.64)$ \\
\hline Ovary & 22 & $0.72(0.47-1.09)$ & 6 & $0.94(0.42-2.08)$ & 10 & $0.65(0.35-1.21)$ & 6 & $0.68(0.31-1.52)$ \\
\hline Prostate & 197 & $1.02(0.88-1.18)$ & 8 & $1.08(0.54-2.17)$ & 65 & $0.99(0.77-1.26)$ & 124 & $1.03(0.86-1.23)$ \\
\hline Testis & 2 & $1.16(0.29-4.64)$ & & & & & & \\
\hline Other male genital organs & 3 & $1.30(0.42-4.02)$ & & & & & & \\
\hline Kidney & 60 & $\mathbf{I . 3 7}(1.06-1.76)$ & 7 & $1.36(0.65-2.85)$ & 27 & $1.27(0.87-1.86)$ & 26 & $\mathbf{I . 5} \mathbf{I}(1.03-2.22)$ \\
\hline Urinary organs & 66 & $1.03(0.8 \mid-1.32)$ & 4 & $0.82(0.3 \mid-2.18)$ & 27 & $1.02(0.70-1.49)$ & 35 & $1.09(0.78-1.52)$ \\
\hline Melanoma & 34 & $1.30(0.92-1.82)$ & 9 & $1.66(0.86-3.21)$ & 16 & $1.54(0.94-2.52)$ & 9 & $0.89(0.46-1.70)$ \\
\hline Squamous cell skin & 47 & $0.88(0.66-1.18)$ & 2 & $0.77(0.19-3.08)$ & 13 & $0.92(0.53-1.59)$ & 32 & $0.88(0.62-1.24)$ \\
\hline Eye & 2 & $0.61(0.15-2.43)$ & & & & & & \\
\hline Nervous system & 33 & $1.00(0.7|-1.4|)$ & 5 & $0.70(0.29-1.69)$ & 20 & $1.21(0.78-1.87)$ & 8 & $0.89(0.45-1.79)$ \\
\hline thyroid gland & 15 & $1.53(0.92-2.54)$ & 4 & $1.77(0.67-4.73)$ & 8 & $1.82(0.9 \mid-3.65)$ & 3 & $0.98(0.32-3.03)$ \\
\hline Endocrine glands & 28 & $1.41(0.97-2.05)$ & 6 & $1.87(0.84-4.17)$ & 12 & $1.27(0.72-2.23)$ & 10 & $1.44(0.77-2.68)$ \\
\hline Connective tissue & 10 & $1.20(0.64-2.23)$ & 2 & $1.57(0.39-6.27)$ & 6 & $1.80(0.81-4.02)$ & 2 & $0.54(0.14-2.17)$ \\
\hline Non-Hodgkin's lymphoma & 31 & $0.86(0.60-1.23)$ & 3 & $0.84(0.27-2.61)$ & 12 & $0.83(0.47-1.46)$ & 16 & $0.89(0.55-1.46)$ \\
\hline Hodgkin's disease & 8 & $1.33(0.66-2.66)$ & & & 3 & $1.06(0.34-3.29)$ & 4 & $2.27(0.85-6.06)$ \\
\hline Leukaemia & 34 & $0.88(0.63-1.24)$ & 4 & $0.98(0.37-2.61)$ & | | & $0.67(0.37-1.22)$ & 19 & $1.06(0.68-1.67)$ \\
\hline
\end{tabular}

Bold signifies $P<0.05$.

patients with pancreatic cancer had an elevated risk of cancers of the testis (RR 1.35; 95\% CI 1.06-1.73) and other male genital organs (RR 1.88; 95\% CI 1.06-3.34). The risk of Hodgkin's disease was elevated among those individuals whose parent was diagnosed with pancreatic cancer after the age of 71 years (RR 1.67; 95\% CI 1.04-2.69). Parental history of pancreatic cancer after the age of 71 years increased the risk of endometrial cancer in women (RR 1.33; 95\% CI 1.04-1.72).

Sibling history of pancreatic cancer tripled the risk of pancreatic cancer (RR 3.26; 95\% CI 2.07-5.12) (Table 4). The risk of pancreatic cancer was elevated among siblings of patients with cancers of the oesophagus (RR 3.39; 95\% CI 1.69-6.79) and liver (RR 2.07; 95\% CI 1.15-3.75). Almost all siblings were diagnosed with cancer of the oesophagus or of the liver after the age of 55 years. Pancreatic cancer risk was elevated among those whose sibling had cancer of the connective tissue (RR 3.12; 95\% CI $1.62-$ $6.00)$. The risk of pancreatic cancer was increased among individuals with a sibling history of male genital organs (RR 3.57; 95\% CI 1.15-11.1). The risk of pancreatic cancer was elevated among those whose sibling had melanoma of the eye (RR 3.26; 95\% CI $1.05-10.1)$. An individual's pancreatic cancer risk was modified by his/her sibling's age of diagnosis of cancers at three sites. An increased risk of pancreatic cancer was noted only for those whose sibling was diagnosed before the age of 56 years with cancers of the breast (RR 1.37; 95\% CI 1.06-1.77) and lung (RR 1.74; 95\% CI 1.01-3.00). Similarly, there was an increased risk of pancreatic cancer among those whose brother had prostate cancer before the age of 56 years (RR 2.36; 95\% CI 1.23-4.54).

To establish the possible association of familial pancreatic cancer with known syndromes that show pancreatic cancer, patients were identified from the Hospital Discharge Register. A total of 1916 patients with chronic pancreatitis were identified and 66 of them were familial cases; 25 pancreatic cancer cases were identified among all patients but none belonged to the familial pancreatitis group. A total of 774 cystic fibrosis patients were identified in the Hospital Discharge Register but none was diagnosed with pancreatic cancer.

\section{DISCUSSION}

Studying the familial aggregation of pancreatic cancer offers a unique opportunity to advance our understanding of pancreatic cancer development. An advantage of this study was that data on familial relationships were obtained from registered sources and tumour diagnoses were histologically confirmed, excluding any type of recall bias. The updated Swedish Family-Cancer Database permitted us to study pancreatic cancer risk not only according to parental but also according to sibling history of cancer.

The small estimated proportion of familial cases of pancreatic cancer in our dataset (3.66\%) was in accordance with earlier calculations (Hemminki et al, 2008).

Familial aggregation of cancer can be because of a shared genetic background or because of common environmental exposures within families. Risks for concordant and discordant cancers in spouses have been estimated elsewhere to quantify cancer risks from the shared environment (Hemminki and Jiang, 2002). That study was restricted to spouses who had one or more children in common and who lived together for at least 15 years after the first child's birth. The analysis showed no increased 
Table 3 Relative risk of tumours (RR) for the offspring of individuals affected by pancreatic cancer

Parental age of diagnosis with pancreatic cancer

\begin{tabular}{|c|c|c|c|c|c|c|c|c|}
\hline \multirow[b]{2}{*}{ Offspring cancer site } & \multicolumn{2}{|r|}{ Any } & \multicolumn{2}{|r|}{$0-55$} & \multicolumn{2}{|r|}{$56-71$} & \multicolumn{2}{|r|}{$72+$} \\
\hline & $\mathbf{N}$ & $\operatorname{RR}(95 \% \mathrm{Cl})$ & $\mathbf{N}$ & $\operatorname{RR}(95 \% \mathrm{Cl})$ & $\mathbf{N}$ & $\operatorname{RR}(95 \% \mathrm{Cl})$ & $\mathbf{N}$ & $\operatorname{RR}(95 \% \mathrm{Cl})$ \\
\hline Salivary glands & 18 & $2.06(1.29-3.29)$ & & & 9 & $2.17(1.13-4.20)$ & 9 & $\mathbf{2 . 4 4}(|.26-4.7|)$ \\
\hline Oesophagus & 21 & $1.16(0.75-1.79)$ & 2 & $1.63(0.41-6.52)$ & 15 & $1.90(1.14-3.16)$ & 4 & $0.45(0.17-1.19)$ \\
\hline Stomach & 47 & $1.13(0.85-1.51)$ & & & 25 & $1.37(0.93-2.03)$ & 21 & $1.05(0.69-1.63)$ \\
\hline Small intestine & 19 & $\mathbf{I . 6 2}(1.02-2.55)$ & & & 5 & $0.95(0.39-2.28)$ & 13 & $2.38(1.38-4.13)$ \\
\hline Liver & 58 & $1.52(1.17-1.98)$ & 5 & $1.80(0.75-4.33)$ & 28 & $1.69(1.16-2.46)$ & 25 & $1.34(0.90-1.99)$ \\
\hline Pancreas & 84 & $1.93(1.55-2.40)$ & 10 & $3.32(1.78-6.18)$ & 41 & $2.19(1.61-2.98)$ & 33 & $1.54(1.09-2.17)$ \\
\hline Larynx & 15 & $1.26(0.75-2.10)$ & & & 7 & $1.32(0.63-2.79)$ & 7 & $1.22(0.58-2.58)$ \\
\hline Lung & 191 & $1.18(1.02-1.36)$ & 19 & $1.66(1.06-2.61)$ & 82 & $1.17(0.94-1.45)$ & 90 & $1.13(0.92-1.39)$ \\
\hline Breast & 726 & $\mathbf{l . 2 1}(1.13-1.31)$ & 75 & $1.32(1.05-1.66)$ & 361 & $1.33(1.20-1.48)$ & 290 & $1.09(0.97-1.22)$ \\
\hline Cervix uteri & 101 & $1.44(1.18-1.76)$ & 13 & $1.35(0.78-2.33)$ & 55 & $\mathbf{I . 6 1}(1.24-2.10)$ & 33 & $1.28(0.9|-| .81)$ \\
\hline Endometrium & 107 & $1.18(0.97-1.42)$ & 5 & $0.80(0.33-1.91)$ & 41 & $1.05(0.77-1.43)$ & 61 & $1.33(1.04-1.72)$ \\
\hline Urinary organs & 110 & $1.11(0.92-1.34)$ & 8 & $1.09(0.55-2.19)$ & 47 & $1.08(0.81-1.44)$ & 55 & $1.15(0.89-1.51)$ \\
\hline Melanoma & 241 & $1.25(1.10-1.42)$ & 32 & $1.47(1.04-2.08)$ & 133 & $1.47(1.24-1.74)$ & 76 & $0.96(0.77-1.21)$ \\
\hline Squamous cell skin & 65 & $1.06(0.83-1.35)$ & 5 & $1.02(0.43-2.46)$ & 27 & $0.99(0.68-1.45)$ & 33 & $1.13(0.81-1.60)$ \\
\hline Eye & 5 & $0.78(0.32-1.88)$ & & & 2 & $0.68(0.17-2.7 I)$ & 3 & $1.06(0.34-3.29)$ \\
\hline Nervous System & 151 & $0.98(0.84-1.15)$ & 21 & $1.13(0.74-1.74)$ & 61 & $0.84(0.66-1.09)$ & 69 & $1.10(0.81-1.40)$ \\
\hline Thyroid gland & 35 & $0.83(0.59-1.16)$ & 8 & $1.49(0.74-2.97)$ & 14 & $0.69(0.41-1.17)$ & 13 & $0.80(0.46-1.38)$ \\
\hline Endocrine glands & 93 & $1.28(1.04-1.57)$ & 15 & $1.96(1.18-3.26)$ & 40 & $1.19(0.87-1.62)$ & 38 & $1.22(0.89-1.68)$ \\
\hline Connective tissue & 25 & $0.99(0.67-1.48)$ & 3 & $0.99(0.32-3.06)$ & 9 & $0.76(0.39-1.46)$ & 13 & $1.28(0.74-2.21)$ \\
\hline Non-Hodgkin's lymphoma & 115 & $1.14(0.94-1.37)$ & 14 & $1.46(0.87-2.47)$ & 51 & $1.11(0.84-1.46)$ & 50 & $1.10(0.83-1.45)$ \\
\hline Hodgkin's disease & 34 & $1.16(0.82-1.62)$ & 6 & $1.35(0.6 \mid-3.02)$ & 11 & $0.77(0.43-1.39)$ & 17 & $1.67(1.04-2.69)$ \\
\hline Leukaemia & 88 & $1.03(0.84-1.27)$ & 10 & $1.03(0.56-1.92)$ & 45 & $1.13(0.85-1.52)$ & 33 & $0.90(0.64-1.27)$ \\
\hline
\end{tabular}

Bold signifies $P<0.05$.

pancreatic cancer risk among spouses of pancreatic cancer patients (Hemminki and Jiang, 2002). In agreement with previous studies, our analysis confirmed an increased risk of pancreatic cancer among individuals with a family history of pancreatic cancer (Hemminki and Li, 2003a; McWilliams et al, 2005). The fact that the risk of pancreatic cancer associated with sibling history was higher might indicate a recessive mode of inheritance. The greater risk in siblings than in offspring could also suggest that anticipation is operative in familial pancreatic cancer (Lerch, 2006; McFaul et al, 2006).

Previous studies reported an increased risk of pancreatic cancer in the offspring of patients with cancers of the pancreas, rectum and lungs (Hemminki and $\mathrm{Li}, 2003 \mathrm{a}$ ). Associations between pancreatic cancer and cancers of the colon, breast and liver have also been described (Hemminki and Li, 2003b; Hemminki and Chen, 2004; Lorenzo Bermejo and Hemminki, 2004). Our analysis confirmed the above-mentioned findings and showed that cancers of the cervix, testis and of other male genital organs may be associated with pancreatic cancer; however, additional studies are necessary to confirm these associations.

Cancer syndromes and mutations could contribute to the observed aggregation of pancreatic cancer with other cancers. Individuals with HNPCC have an increased risk of carcinoma of the endometrium, ovary, stomach, small bowel, pancreas and brain (Lynch and de la Chapelle, 2003). Association of pancreatic cancer in our study with colon and small intestinal cancers may indicate the presence of HNPCC in some families in the Swedish FamilyCancer Database (Lynch and de la Chapelle, 2003). Inherited mutations of the CDKN2A tumour suppressor gene have been reported in pancreatic cancer patients with a family history of melanoma (Goldstein et al, 1995; Vasen et al, 2000). The BRCA2 gene might also be involved in the observed aggregations of pancreatic cancer with other cancers (for example, breast, prostate). Mutations of BRCA2 were implicated in cancers of the pancreas (Thorlacius et al, 1996; Couch et al, 2007) and breast (FitzGerald et al, 1996; Gayther and Ponder, 1997). Germ line mutations of BRCA2 were also linked to early-onset prostate cancer (Agalliu et al, 2007). Our analysis showed that early age of onset of sibling breast cancer increased an individual's risk of pancreatic cancer. We also found that there was an increased risk of pancreatic cancer associated with early-onset prostate cancer in siblings. The risk of breast cancer was also increased among offspring of pancreatic cancer patients.

An approximately twofold increased risk for pancreatic cancer was observed among ever smokers compared with non-smokers (Fuchs et al, 1996; Muscat et al, 1997; Hassan et al, 2007). Smoking is also a major risk factor of lung, oesophagus and kidney cancers (Chiu et al, 2001; Ghaneh et al, 2007). In accordance with previous studies, we found that pancreatic cancer was associated with other tobacco-related cancers (oesophagus, lung and kidney) (Hemmin$\mathrm{ki}$ and $\mathrm{Li}, 2003 \mathrm{a}$; Shen et al, 2006). In addition, reverse analysis showed that early onset of pancreatic cancer in parents was positively associated with the risk of lung cancer in offspring.

Hereditary pancreatitis and cystic fibrosis are known but rare risk factors of pancreatic cancer (Howes et al, 2004; Maisonneuve et al, 2007; Rebours et al, 2009). However, using the nation-wide Hospital Discharge Register for case identification, no pancreatic cancer could be linked to these causes. In a European study on 418 patients from hereditary pancreatitis families, $26(6 \%)$ were diagnosed with pancreatic cancer but close to $70 \%$ of the cancer 
Table 4 Relative risk of pancreatic cancer (RR) diagnosed in siblings of individuals affected by cancer

\begin{tabular}{|c|c|c|c|c|c|c|}
\hline \multirow[b]{3}{*}{ Sibling cancer site } & \multicolumn{6}{|c|}{ Age of diagnosis of siblings with cancer } \\
\hline & \multicolumn{2}{|c|}{ Any age } & \multicolumn{2}{|c|}{$0-55$} & \multicolumn{2}{|c|}{$56-71$} \\
\hline & $\mathbf{N}$ & RR (95\% CI) & $\mathbf{N}$ & RR (95\% Cl) & $\mathbf{N}$ & RR (95\% Cl) \\
\hline Upper aerodigestive tract & 8 & $1.28(0.64-2.57)$ & 6 & $2.03(0.9 \mid-4.53)$ & 2 & $0.61(0.15-2.45)$ \\
\hline Oesophagus & 8 & $3.39(1.69-6.79)$ & 2 & $3.16(0.79-12.6)$ & 6 & $\mathbf{3 . 4 9}(1.57-7.77)$ \\
\hline Stomach & 9 & $1.35(0.70-2.59)$ & 3 & $1.13(0.36-3.50)$ & 6 & $|.5|(0.68-3.37)$ \\
\hline Colon & 18 & $0.96(0.60-1.53)$ & 7 & $0.96(0.46-2.01)$ & || & $0.96(0.53-1.74)$ \\
\hline Rectum & 13 & $1.09(0.63-1.89)$ & 3 & $0.69(0.22-2.15)$ & 10 & $1.32(0.71-2.46)$ \\
\hline Liver & $\mid 1$ & $2.07(1.15-3.75)$ & & & 10 & $\mathbf{2 . 8 8}(1.55-5.36)$ \\
\hline Pancreas & 19 & $3.26(2.07-5.12)$ & 9 & $\mathbf{5 . 0 6}(2.63-9.74)$ & 10 & $\mathbf{2 . 4 7}(1.33-4.59)$ \\
\hline Larynx & 2 & I.I। (0.28-4.46) & & & & \\
\hline Lung & 25 & $1.09(0.73-1.61)$ & 13 & $\mathbf{I . 7 4}(1.01-3.00)$ & 12 & $0.77(0.44-1.37)$ \\
\hline Breast & 88 & $1.19(0.96-1.48)$ & 59 & $\mathbf{I . 3 7}(1.06-1.77)$ & 29 & $0.95(0.66-1.38)$ \\
\hline Cervix uteri & 7 & $0.79(0.38-1.65)$ & 6 & $0.79(0.35-1.75)$ & & \\
\hline Endometrium & 18 & $1.50(0.95-2.39)$ & 8 & $1.68(0.84-3.36)$ & 10 & $1.39(0.75-2.59)$ \\
\hline Ovary & $\mid 1$ & $0.95(0.52-|.7|)$ & 9 & $1.26(0.66-2.43)$ & 2 & $0.45(0.11-1.82)$ \\
\hline Prostate & 47 & $1.19(0.89-1.59)$ & 9 & $2.36(1.23-4.54)$ & 38 & $1.07(0.77-1.47)$ \\
\hline Testis & 4 & $1.09(0.41-2.90)$ & 3 & $0.88(0.28-2.72)$ & & \\
\hline Other male genital organs & 3 & $\mathbf{3 . 5 7}(1.15-11.1)$ & 3 & $6.48(2.09-20.1)$ & & \\
\hline Kidney & $1 \mid$ & $1.17(0.65-2.11)$ & 8 & $1.86(0.93-3.73)$ & 3 & $0.59(0.19-1.84)$ \\
\hline Urinary organs & 17 & $1.24(0.77-2.00)$ & 9 & $1.64(0.85-3.16)$ & 8 & $0.98(0.49-1.96)$ \\
\hline Melanoma & 19 & $0.94(0.60-1.48)$ & 13 & $0.98(0.57-1.69)$ & 6 & $0.88(0.39-1.95)$ \\
\hline Squamous cell skin & 10 & $1.31(0.70-2.44)$ & 4 & $1.31(0.49-3.49)$ & 6 & $1.31(0.59-2.93)$ \\
\hline Eye & 3 & $3.26(1.05-10.1)$ & 3 & $\mathbf{4 . 7 0}(1.52-\mid 4.6)$ & & \\
\hline Nervous system & 15 & $0.88(0.53-1.45)$ & 10 & $0.92(0.49-1.71)$ & 5 & $0.80(0.33-1.93)$ \\
\hline Endocrine glands & 13 & $1.38(0.80-2.39)$ & 5 & $0.81(0.34-1.95)$ & 8 & $\mathbf{2 . 5 1}(1.25-5.02)$ \\
\hline Connective tissue & 9 & $3.12(1.62-6.00)$ & 5 & $2.70(1.12-6.50)$ & 4 & $\mathbf{3 . 8 7}(1.45-10.3)$ \\
\hline Hodgkin's disease & 3 & $1.08(0.35-3.36)$ & 3 & $1.25(0.40-3.89)$ & & \\
\hline Non-Hodgkin's lymphoma & 10 & $0.76(0.4|-| .4 \mid)$ & 6 & $0.87(0.39-1.95)$ & 4 & $0.63(0.24-1.69)$ \\
\hline Leukaemia & 8 & $0.88(0.44-1.75)$ & 7 & $1.54(0.73-3.24)$ & & \\
\hline
\end{tabular}

Bold signifies $P<0.05$.

cases were diagnosed 50 or more years after the diagnosis of pancreatitis (Howes et al, 2004). However, our maximal follow-up time was 43 years, of which only 21 years were with a full national coverage, decreasing the chances of finding a relationship between the two diseases. Pancreatic cancer is a rare complication after cystic fibrosis and the risk of estimation has been based on international case collections (Maisonneuve et al, 2007).

A potential limitation of our study was the unavailability of information on other potential risk factors of pancreatic cancer such as tobacco smoking, alcohol consumption and diet. It is important to note that some of the significant associations could be attributed to chance as well. Our investigation was also limited by the small number of tumours at some locations. The problem could be alleviated when future updates of the Swedish FamilyCancer Database are available.

The present results on the aggregation of pancreatic cancer with other cancers in Swedish families suggest that pancreatic cancer shares a genetic and/or environmental aetiology with cancer at several sites. The results of this study demonstrated a familial association of pancreatic tumours with cancers of the lung, liver and kidney. An association was also found between pancreatic cancer in parents and melanoma in offspring. Individuals with a parental history of pancreatic cancer showed an increased risk of small intestine, colon, lung, breast, testicular and cervical cancers. There was an elevated risk of pancreatic cancer among those whose sibling had lung cancer before the age of 56 years. Some of the observed associations might be related to smoking and mutations in genes such as BRCA2.

\section{ACKNOWLEDGEMENTS}

Supported by Deutsche Krebshilfe, the Swedish Cancer Society, the Swedish Council for Working Life and Social Research, and the EU, LSHCCT-2004-503465. The Family-Cancer Database was created by linking registers maintained at Statistics Sweden and the Swedish Cancer Registry.

\section{Conflict of interest}

The authors declare no conflict of interest.

\section{REFERENCES}

Agalliu I, Karlins E, Kwon EM, Iwasaki LM, Diamond A, Ostrander EA, Stanford JL (2007) Rare germline mutations in the BRCA2 gene are associated with early-onset prostate cancer. $\mathrm{Br}$ J Cancer 97: 826-831

Center for Epidemiology (2004) Cancer Incidence in Sweden 2002. The National Board of Health and Welfare: Stockholm

Chiu BC, Lynch CF, Cerhan JR, Cantor KP (2001) Cigarette smoking and risk of bladder, pancreas, kidney, and colorectal cancers in Iowa. Ann Epidemiol 11: 28-37

Couch FJ, Johnson MR, Rabe KG, Brune K, de Andrade $M$, Goggins M, Rothenmund H, Gallinger S, Klein A, Petersen GM, Hruban RH (2007) The prevalence of BRCA2 mutations in familial pancreatic cancer. Cancer Epidemiol Biomarkers Prev 16: $342-346$

Coughlin SS, Calle EE, Patel AV, Thun MJ (2000) Predictors of pancreatic cancer mortality among a large cohort of United States adults. Cancer Causes Control 11: 915-923 
Engholm G, Ferlay J, Christensen N, Bray F, Klint A, Olafsdóttir E, Pukkala E, Storm H (2008) NORDCAN: Cancer Incidence, Mortality and Prevalence in the Nordic Countries, version 3.2. Association of Nordic Cancer Registries. Danish Cancer Society

FitzGerald MG, MacDonald DJ, Krainer M, Hoover I, O'Neil E, Unsal H, Silva-Arrieto S, Finkelstein DM, Beer-Romero P, Englert C, Sgroi DC, Smith BL, Younger JW, Garber JE, Duda RB, Mayzel KA, Isselbacher KJ, Friend SH, Haber DA (1996) Germ-line BRCA1 mutations in Jewish and non-Jewish women with early-onset breast cancer. New Engl J Med 334: $143-149$

Fuchs CS, Colditz GA, Stampfer MJ, Giovannucci EL, Hunter DJ, Rimm EB, Willett WC, Speizer FE (1996) A prospective study of cigarette smoking and the risk of pancreatic cancer. Arch Int Med 156: 2255-2260

Gayther SA, Ponder BA (1997) Mutations of the BRCA1 and BRCA2 genes and the possibilities for predictive testing. Mol Med Today 3: 168-174

Ghaneh P, Costello E, Neoptolemos JP (2007) Biology and management of pancreatic cancer. Gut 56: 1134-1152

Goldstein AM, Fraser MC, Struewing JP, Hussussian CJ, Ranade K, Zametkin DP, Fontaine LS, Organic SM, Dracopoli NC, Clark Jr WH, Tucker MA (1995) Increased risk of pancreatic cancer in melanomaprone kindreds with p16INK4 mutations. New Engl J Med 333: 970 - 974

Greenhalf W, Neoptolemos JP (2006) Increasing survival rates of patients with pancreatic cancer by earlier identification. Nat Clin Practice 3: $346-347$

Greer JB, Whitcomb DC, Brand RE (2007) Genetic predisposition to pancreatic cancer: a brief review. Am J Gastroenterol 102: 2564-2569

Hassan MM, Abbruzzese JL, Bondy ML, Wolff RA, Vauthey JN, Pisters PW, Evans DB, Khan R, Lenzi R, Jiao L, Li D (2007) Passive smoking and the use of noncigarette tobacco products in association with risk for pancreatic cancer: a case-control study. Cancer 109: 2547-2556

Hemminki K, Chen B (2004) Familial association of colorectal adenocarcinoma with cancers at other sites. Eur J Cancer 40: 2480-2487

Hemminki K, Jiang Y (2002) Cancer risks among long-standing spouses. $\mathrm{Br}$ J Cancer 86: $1737-1740$

Hemminki K, Li X (2003a) Familial and second primary pancreatic cancers: a nationwide epidemiologic study from Sweden. Int J Cancer 103: 525-530

Hemminki K, Li X (2003b) Familial liver and gall bladder cancer: a nationwide epidemiological study from Sweden. Gut 52: 592-596

Hemminki K, Li X, Plna K, Granstrom C, Vaittinen P (2001) The nationwide Swedish family-cancer database-updated structure and familial rates. Acta oncologica (Stockholm, Sweden) 40: $772-777$

Hemminki K, Li X, Sundquist K, Sundquist J (2009) Shared familial aggregation of susceptibility to autoimmune diseases. Arthritis Rheum 60: $2845-2847$

Hemminki K, Sundquist J, Bermejo JL (2008) How common is familial cancer? Ann Oncol 19: $163-167$

Hemminki K, Vaittinen P (1999) Familial cancers in a nationwide family cancer database: age distribution and prevalence. Eur J Cancer 35: $1109-1117$

Hemminki K, Vaittinen P, Kyyronen P (1998) Age-specific familial risks in common cancers of the offspring. Int J Cancer 78: $172-175$

Howes N, Lerch MM, Greenhalf W, Stocken DD, Ellis I, Simon P, Truninger K, Ammann R, Cavallini G, Charnley RM, Uomo G, Delhaye M, Spicak J, Drumm B, Jansen J, Mountford R, Whitcomb DC, Neoptolemos JP (2004) Clinical and genetic characteristics of hereditary pancreatitis in Europe. Clin Gastroenterol Hepatol 2: 252-261

Jaffee EM, Hruban RH, Canto M, Kern SE (2002) Focus on pancreas cancer. Cancer Cell 2: 25-28
Klein AP, Beaty TH, Bailey-Wilson JE, Brune KA, Hruban RH, Petersen GM (2002) Evidence for a major gene influencing risk of pancreatic cancer. Genet Epidemiol 23: 133-149

Klein AP, Hruban RH, Brune KA, Petersen GM, Goggins M (2001) Familial pancreatic cancer. Cancer J 7: 266-273

Krainer M, Silva-Arrieta S, FitzGerald MG, Shimada A, Ishioka C, Kanamaru R, MacDonald DJ, Unsal H, Finkelstein DM, Bowcock A, Isselbacher KJ, Haber DA (1997) Differential contributions of BRCA1 and BRCA2 to early-onset breast cancer. New Engl J Med 336: 1416-1421

Lerch MM (2006) Anticipating disaster: the genetics of familial pancreatic cancer. Gut 55: 150 - 151

Linder S, Bostrom L, Nilsson B (2007) Pancreatic carcinoma incidence and survival in Sweden in 1980-2000: a population-based study of 16758 hospitalized patients with special reference to different therapies. Eur J Surg Oncol 33: 616-622

Lorenzo Bermejo J, Hemminki K (2004) Familial association of histology specific breast cancers with cancers at other sites. Int J Cancer 109: $430-435$

Lynch HT, de la Chapelle A (2003) Hereditary colorectal cancer. New Engl J Med 348: 919-932

MacLeod SL, Chowdhury P (2006) The genetics of nicotine dependence: relationship to pancreatic cancer. World J Gastroenterol 12: 7433-7439

Maisonneuve P, Marshall BC, Lowenfels AB (2007) Risk of pancreatic cancer in patients with cystic fibrosis. Gut 56: $1327-1328$

McFaul CD, Greenhalf W, Earl J, Howes N, Neoptolemos JP, Kress R, SinaFrey M, Rieder H, Hahn S, Bartsch DK (2006) Anticipation in familial pancreatic cancer. Gut 55: 252-258

McWilliams RR, Rabe KG, Olswold C, De Andrade M, Petersen GM (2005) Risk of malignancy in first-degree relatives of patients with pancreatic carcinoma. Cancer 104: 388 - 394

Michaud DS, Giovannucci E, Willett WC, Colditz GA, Stampfer MJ, Fuchs CS (2001) Physical activity, obesity, height, and the risk of pancreatic cancer. JAMA 286: 921 -929

Muscat JE, Stellman SD, Hoffmann D, Wynder EL (1997) Smoking and pancreatic cancer in men and women. Cancer Epidemiol Biomarkers Prev 6: $15-19$

Raimondi S, Maisonneuve P, Lohr JM, Lowenfels AB (2007) Early onset pancreatic cancer: evidence of a major role for smoking and genetic factors. Cancer Epidemiol Biomarkers Prev 16: 1894-1897

Rebours V, Boutron-Ruault MC, Schnee M, Ferec C, Le Marechal C, Hentic O, Maire F, Hammel P, Ruszniewski P, Levy P (2009) The natural history of hereditary pancreatitis: a national series. Gut 58: $97-103$

Rulyak SJ, Brentnall TA (2004) Inherited pancreatic cancer: improvements in our understanding of genetics and screening. Int J Biochem Cell Biol 36: $1386-1392$

Shen M, Boffetta P, Olsen JH, Andersen A, Hemminki K, Pukkala E, Tracey E, Brewster DH, McBride ML, Pompe-Kirn V, Kliewer EV, Tonita JM, Chia KS, Martos C, Jonasson JG, Colin D, Scelo G, Brennan P (2006) A pooled analysis of second primary pancreatic cancer. Am J Epidemiol 163: $502-511$

Thorlacius S, Olafsdottir G, Tryggvadottir L, Neuhausen S, Jonasson JG, Tavtigian SV, Tulinius H, Ogmundsdottir HM, Eyfjord JE (1996) A single BRCA2 mutation in male and female breast cancer families from Iceland with varied cancer phenotypes. Nat Genet 13: 117-119

Vasen HF, Gruis NA, Frants RR, van Der Velden PA, Hille ET, Bergman W (2000) Risk of developing pancreatic cancer in families with familial atypical multiple mole melanoma associated with a specific 19 deletion of p16 (p16-Leiden). Int J Cancer 87: 809-811 